\title{
Population Reduction, Unification of Curriculum and Diversification of Financial Support of Secondary Education in the Czech Republic: The Situation in the Years 2006 - 2016
}

\author{
Ilona Kočvarová* \\ Received: February 8, 2017; received in revised form: March 12, 2017; \\ accepted: March 13, 2017
}

\begin{abstract}
:
Introduction: The article focuses on the situation in the area of secondary education in the Czech Republic. Its aim is to reflect three topics: population reduction, unification of curriculum and diversification of financial support of secondary education in the Czech Republic in 2006 2016.

Methods: The results are underlined by available data from the national statistics. The data are collected annually and are accessible on the website of the Ministry of Education, Youth and Sports. They contain the entire population of secondary schools, teachers and pupils. Analysis was provided with the use of SPSS, version 24.
\end{abstract}

Results: There is a reduction of vocational and apprentice schools, but at the same time we are increasing financial support to their fields of study. Under the 2004 law, each school has an individual school educational program, but realistically, we see that the curriculum at secondary school level of education rather standardises. On the labour market, we need graduates of vocational and apprentice schools, but we still strongly support grammar schools and other theoretically oriented schools, whose graduates are not motivated for manual professions.

Discussion: Closer analysis focused on reflection of selected trends in the area of secondary education is needed for the purposes of education policy and for planning future research studies in this area.

Limitations: Continuous development takes place in the field of education. All comparisons in the years 2006 - 2016 are therefore limited. The data were used in their original form, in some cases were not available and therefore they could not be included in the analysis.

Ilona Kočvarová, Faculty of Humanities, University of Tomas Bata in Zlín, Zlín, Czech Republic; kocvarova@fhs.utb.cz 


\title{
Acta Technologica Dubnicae \\ volume 7,2017 , issue 1
}

\begin{abstract}
Conclusions: Educational policy is very complicated, because education is difficult to control and it is based on freedom of access. Therefore, the most important target for the future is to stabilize the situation and be able to reflect maximum of factors influencing secondary education in our society. Although current trends clearly support lifelong learning and its unification, we should not forget the specific fields of apprentice and vocational schools, which are needed on the labour market.
\end{abstract}

Key words: the Czech Republic, secondary education, education policy, school financing, normatives ${ }^{1}$.

\section{Introduction}

In the article, we highlight the current situation of secondary education in the Czech Republic, especially trends and problems, which are mainly apparent in this area in the years $2006-2016 .{ }^{2}$

Secondary education is a traditional part of the Czech educational system at ISCED $2-4$ (Eurostat, 2016). This level follows up on the compulsory primary education and offers a wide range of possibilities: shorter one or two years long studies without a certificate of apprenticeship, three years of study with a certificate of apprenticeship, four-year program ending with school-leaving examination known as maturita (in this text also mentioned as graduation exam), but also various superstructure courses and shortened studies. Grammar schools, lyceums, vocational schools, apprentice schools and conservatoires are at the secondary school level. Currently, we are witnessing the merging of different types of secondary schools. The ratio of public, private and church schools is about 25:8:1. Regions establish about $95 \%$ of public schools and the proportion of this type of schools is slightly decreasing in long-term evolution (MEYS ${ }^{3}$, 2016). More general information about the status of secondary schools in the Czech educational system is available in the document EACEA ${ }^{4}$ (2009).

Several key factors influence the current form of secondary education, mainly the transformation of the educational system after 1989, following legislative changes, significant decentralization in education (in comparison to other European countries), but also a major curricular reform in the transition to new

\footnotetext{
${ }^{1}$ In this text we use the expression "normatives" to talk about the guaranteed amount of money paid regularly by regions to schools for each pupil (per capita). It could also be translated as standards or norms.

${ }^{2}$ Barták's overview report (2004) discusses the earlier situation especially on the level of vocational training.

${ }^{3}$ The Ministry of Education, Youth and Sports

${ }^{4}$ Education, Audiovisual and Culture Executive Agency
} 


\section{Acta Technologica Dubnicae \\ volume 7,2017 , issue 1}

curricular framework (state educational program and individual school educational programs, in Czech known under the abbreviations as RVP and ŠVP). The social and economic situation leads to a changing conception of schools. Their workers begin to apply market-oriented strategies, because they have to fight for their place on the educational market. It manifests a trend that can be, in our view, described as a "reverse competition" where schools are struggling for pupils, but pupils can choose nearly any school regardless of their abilities, which generally leads to a reduction in standards and seriousness of education in our society ${ }^{5}$. The situation at the same time forces school workers to implement marketing activities, benchmarking and other efforts to create a positive image. Basic documents of educational policy, such as the White Paper (2001), regularly published long-term plans for education (hereinafter LPE, the last of 2015) and the Strategy for Education Policy of the Czech Republic until 2020 (MEYS, 2014), reflect and predict the situation of secondary schools in the long term.

State graduation exams, unified final exams for apprenticeship programs, promotion of inclusive education, the approval of the career system of teaching profession, or the upcoming state-regulated compulsory entrance exams for courses ended with state graduation exams are among the latest innovations at this level. However, we still struggle to optimize the system of financing schools (currently there is an effort to differentiate normative financing according to the needs of the labour market and complement it more by project financing). Another issue is problematic expansion of cooperation between educational institutions and entities providing practice to pupils, or stronger motivation of pupils to study technical and practically oriented disciplines. New changes are constantly stretching the post-revolutionary transformation. School workers must adapt to them flexibly. Often, however, difficult and sometimes conflicting interventions can be recorded in the Czech educational policy and practice (e.g. the establishment of an autonomous approach to the creation of school educational programs known as ŠVP, which was subsequently completed by unified state graduation exams, etc.).

\footnotetext{
${ }^{5}$ We consider reducing standards of education particularly with regard to the exigence of studies, which may be reflected with the use of data on student performance in the first round of admission procedure in secondary schools. It rose from 80\% in 2006 to $83 \%$ in 2009. After changing the rules of admission procedure (MEYS, 2009) the success rate dropped sharply to $59 \%$, but since then it has been continually rising to $73 \%$ in 2016. We expect, however, that the following year will bring another downturn, because all pupils will have to take compulsory entrance exams for all graduation disciplines. Given that schools are still mainly founded according to normatives based on the number of their pupils, it is clear that they are forced to recruit the largest possible number of pupils each year, which in turn limits the demands placed on them.
} 


\section{Acta Technologica Dubnicae \\ volume 7,2017 , issue 1}

Information on the status and development of secondary education are regularly updated in the aforementioned documents on educational policy, but also in the outputs of the Czech School Inspectorate, also in national and international studies. Nevertheless, we still lack a closer analysis focused on reflection and context of selected trends and issues manifesting themselves in this area. In the following chapters we will focus on three topics as already mentioned.

\section{Methodology}

The study is based on quantitative analysis of publicly available data from the fields of national and regional education, which are available on the website of the Ministry of Education, Youth and Sports (MEYS, 2017a-d) in section Statistical Yearbook of Education and also in section Normatives. The analysis was provided with the use of statistical software SPSS, version 24 . We focused on regional normatives of public schools because they are the most represented in the Czech educational system and the vast majority of them (about 95\%) are set up by regions. We focused on information relating to the years $2006-2016$. The data are collected annually by the state under Decree no. 364/2005 Coll. about documentation of schools and educational institutions, as amended, which are used for monitoring the development in selected areas of educational reality. The research group consists of the entire secondary school population in the Czech Republic (schools, pupils and teachers). The analysis uses data in the original structure (e.g. school types, etc.) and preserves the monitored variables in their original form.

The analysis is based on combining various data about schools, pupils and teachers. We attempt to put them into context in order to understand trends in ten years of development. In the chapter devoted to the diversification of financial support we do not monitor development in each year, but only compare the years 2006 and 2016. That is because we want to highlight the differences that could appear as subtle and confusing at the annual development continuum. Our intention is not to present detailed information on each of the monitored variables, because these data are available on the website of the ministry of education, and also because it is a really big amount of data from which we select only the most relevant for the purposes of this study. We focus on three topics: population reduction, unification of curriculum and diversification of financial support of secondary education in the Czech Republic in 2006 - 2016. Our intention is to underpin them with available data. The usability of this analysis is primarily in the area of education policy, because it is important to discuss the information about the current state of secondary education in the Czech Republic, but it also plays an important role in the planning and execution of research studies in education, where it is necessary to know the basic information about the structure of the research population. 


\section{Acta Technologica Dubnicae \\ volume 7, 2017, issue 1}

\section{Results}

Outputs from the analysis are divided into the following three sections which reflect the announced topics.

\subsection{Reduction of secondary school population}

Long-term reduction of secondary school population is not surprising, but we still consider it appropriate to present and discuss the selected parameters of this area. Abolition and merging of secondary schools follows the wave of reduction in the field of nursery schools (especially in the years 2001 - 2004), followed by primary schools (2004 - 2007) and was most evident in 2007, when it touched 522 schools. The most fundamental cause of the reduction can clearly be declining demographic curve. Despite the decreasing number of schools, they are still filled in average by $60 \%$ (LPE 2015 - 2020, p. 22), but their capacities are still waiting for a short-term increase in the number of pupils who currently attend primary schools. According to forecasts in LPE 2015 - 2020 (p. 20) there will be a turnover in 2017 and the number of pupils entering the first year of secondary schools will slightly increase. But then again, it will stagnate and in some regions of the Czech Republic fall. If we focus on three basic segments of the secondary school population (schools, pupils, teachers), their abundance has been decreasing over the past 10 years, as shown in the graph in Figure 1. Since 2006 the number of schools has decreased to $65 \%$, teachers to $81 \%$ and pupils to $74 \%$. Although the numbers of pupils in relation to teachers decline more markedly, we cannot assume more radical reduction in the number of teachers because they represent a diverse branch structure of secondary education and their interchangeability is not possible. Teachers with various specializations therefore remain at schools to implement teaching in their specific subjects even at the cost of fewer pupils. Often, however, teachers are forced to broaden their specialization to be usable in more areas and keep full-time jobs.

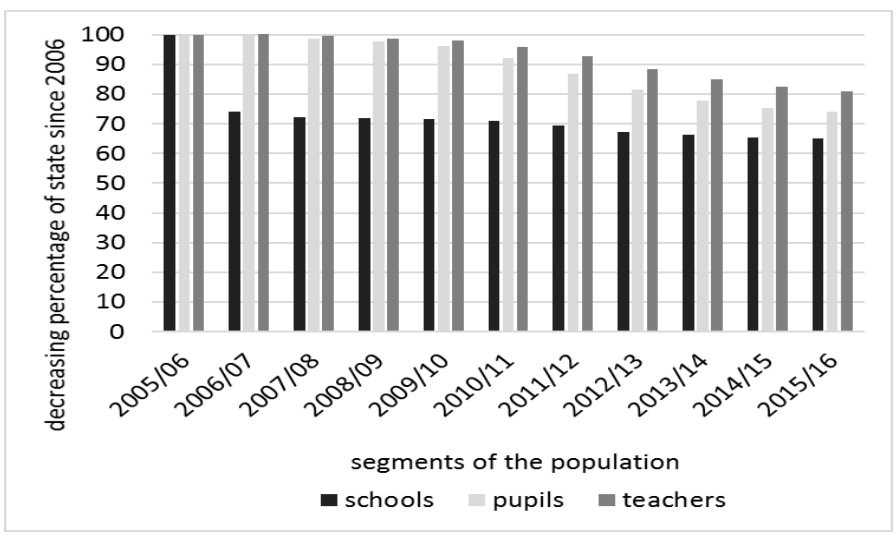

Figure 1. Decreasing secondary school population. 


\section{Acta Technologica Dubnicae \\ volume 7, 2017, issue 1}

Decreasing numbers of teachers do not indicate that there is no need to prepare their new generation at pedagogical faculties. Above all, we know the situation in practice. There is a fairly significant turnover in schools (especially a shortage of language teachers, IT specialists and specialists for technical subjects). We also know that the population of secondary school teachers is dramatically aging (in the category of teachers aged 56 years and over, there is $29 \%$ of teachers in 2016, while in 2006 it was 20\%, and in the other categories there is also evident shift toward higher age boundaries). It is therefore entirely pragmatic to prepare and motivate new teachers. ${ }^{6}$

The situation does not only have negative consequences. The average number of pupils per teacher decreased from 12.2 pupils in 2006 to 11.1 pupils in 2016 . However, according to our experience, the number of pupils per teacher is dramatically different in various types of schools (grammar schools are currently filled with some of $80 \%$ of their capacity, while the other secondary schools roughly $60 \%$ ). The situation must also be seen due to the focus of teachers. On the one hand, generally focused Czech language teachers must cope with large classes, which are often built from merged fields of study, on the other hand, specialists in technical areas deal with much smaller groups.

Declining numbers of secondary schools contrast with the sharp increase in the number of private secondary schools especially after the revolution in 1989 . Nearly 500 private secondary schools were open in the years 1990 - 1997 (Development Report, p. 17). Liberal education policy did not reflect sharply declining demographic curve at that time. Probably, it was believed that it was a short-term trend, although it was apparent that the demographics of the Czech population approximates the Western European model (EACEA, 2009, p. 17). At present, however, we assume (using predictive statistical models), that the birth rate in the Czech Republic will continue to decline (LPE 2015- 2020, p. 9).

Along with the declining number of schools we also monitor their structure by founder and focus. It turns out that the biggest wave of abolition (hence merging) schools in 2007 hit mainly vocational and apprentice schools of public

${ }^{6}$ In this context, we consider it appropriate to mention at least marginally more problematic aspects of the situation of secondary school teachers. Their medially proclaimed average gross wage increased to $138 \%$ in 2016 compared to 2006 . But in terms of real wages (at constant 2005 prices) it only raised to $104 \%$ of state from 2006 , so their salaries actually just replicate growing inflation. The situation of teachers doesn't seem much better, although they are forced to enhance their education (from $88 \%$ in 2006 to $92 \%$ of university-educated secondary school teachers in 2016) and they must also adapt to the newly introduced career system (MEYS, 2016; Janík, Spilková, \& Píšová, 2014). 


\section{Acta Technologica Dubnicae \\ volume 7,2017 , issue 1}

type. Along with these types of schools the percentage of their pupils obviously decreased (from 73\% in 2006 to 67\% in 2016). This issue has implications for the next part of the analysis presented in the following subchapter.

\subsection{Unification of secondary education}

In this section, we present data on the structure of secondary education in the Czech Republic, where we notice the ratio of vocational schools (including lyceums), apprentice schools and grammar schools, but we also focus on the relationship between graduation and apprenticeship programs.

Current secondary schools lose their traditional professionalization function (preparation for the performance of a specific profession), on the contrary, they have increasingly important transit function in the educational system. It means that the schools no longer provide a comprehensive preparation before taking up employment for the majority of the population, but represent a transition between compulsory primary and tertiary education. It is consistent with current trends since the European Union has been trying to increase the proportion of highly educated population in all member states. The situation leads to a progressive unification and generalization of the curriculum of secondary schools (contrary to the development of individual school educational programmes after 2004). They increasingly serve as preparation for lifelong learning ${ }^{7}$ (more in Hužovičová \& Jakúbek, 2014). White Paper (2001, p. 28, 51) points to this trend as well. Support is directed towards multifunctional, integrated, widely profiled, not narrowly specific fields of study. The aim is to promote permeability within the educational system and variability of branches to be flexible with regard to labour market requirements (Ibid, p. 52).

As well as vocational schools and lyceums, grammar schools are also changing. They do not hold the role of purely academic preparation any more, but they are becoming general educational schools which are open to a wide range of candidates. They are still primarily preparing pupils to universities, but they also focus on transferable skills into practice.

Since founders of schools still strongly support graduation fields of study, the percentage of pupils at apprentice courses continuously decreases (from an already low ratio of $23.6 \%$ in 2006 to $21.5 \%$ in 2016). The development is questionable given the current demands of the labour market and in a situation where quality of the candidates for graduation fields of study decreases (which is

\footnotetext{
${ }^{7}$ JuSeuk (2016) constructed a GLLI index (global lifelong learning index) which can be used to make comparisons among countries. Czech Republic placed on the 27. place out of 81 countries and our result was strong among countries with medium economy (according to GDP per capita).
} 


\section{Acta Technologica Dubnicae \\ volume 7,2017 , issue 1}

why in 2017 we are introducing state-regulated compulsory entrance exams for these courses). This situation was foreseen in the White Paper (2001, p. 29). The document envisaged a roughly $25 \%$ share of pupils at apprentice fields.

Despite the criticism of support in the area of graduation courses and grammar schools, we should emphasize that current graduates of grammar schools have the lowest unemployment rate in comparison to other graduates (in 2014 around $4 \%$ ), graduates from vocational secondary schools with graduation exam have a slightly larger problem finding a job (in 2014, 10-14\% in various types of fields) and graduates of apprentice schools are the least successful (18\% in 2014). This is paradoxical due to the demands of labour offices. These proportions do not change rapidly in terms of the national average in the long term, but they differ markedly in terms of regions (more in LPE 2015-2020, p. 23-24). But the question is whether our society creates artificial jobs suitable for workers with general education and at the same time artificially increases the employment of graduates of grammar schools, while companies vainly bid for specialized and manually oriented professions.

\subsection{Diversification of financial support of secondary education}

In this area, we focus on differences in regional normatives per pupil. Basic rules for their establishment are governed by Decree no. 492/2005 Coll., on regional normatives per pupil, as amended. Of course, continual development takes place in this area and the specifics of individual regions are strikingly evident. They differ mainly in the area of labour market requirements, but also demographic characteristics, etc.

First, we present a breakdown by fields according to the Classification of Core Fields (NUV, (C) 2016), which are also specified by Government Regulation no. 211/2010 Coll. These courses are divided according to their endings: graduation fields (ending with school leaving examination - maturita) and vocational apprentice training (ended with certificate of apprenticeship), as shown in Table 1. 
Table 1

Basic classification of fields of secondary education in the Czech Republic

\begin{tabular}{lll}
\hline $\begin{array}{l}\text { Category } \\
\text { of fields }\end{array}$ & $\begin{array}{l}\text { Levels of education } \\
\mathrm{H}\end{array}$ & $\begin{array}{l}\text { Length of } \\
\text { study }\end{array}$ \\
\hline $\mathrm{K}$ & $\begin{array}{l}\text { Secondary education with apprenticeship certificate } \\
\text { Secondary education with graduation exam (general }\end{array}$ & 3 years \\
\hline $\mathrm{L}$ & $\begin{array}{l}\text { Secondary education with graduation exam (vocational } \\
\text { education with vocational training) }\end{array}$ & 4 years \\
\hline $\mathrm{M}$ & $\begin{array}{l}\text { Secondary education with graduation exam (lyceum or } \\
\text { vocational education) }\end{array}$ & 4 years \\
\hline
\end{tabular}

Some types of fields are not included in the table and analysis, because their conditions are strongly different in compared years, namely the fields marked $\mathbf{J}$ (one or two years long practical school for graduates of special elementary school) and E (two years long vocational courses without an apprenticeship certificate within special schools). The analysis does not reflect the sub-groups of fields (especially superstructure and shortened courses). We also do not include analysis of conservatories as a specific element of education at secondary school level.

In our analysis, we focus on the issue of diversification of financial support in different categories of education and also fields of study, namely on the normative financing. In the case of fields where vocational training is implemented, we add the amount for theoretical and vocational training together.

A fairly significant development of educational fields occurred between 2006 and 2016. Therefore, only the fields existing in the two years could be included in the comparison. We held the following criteria: compared fields exist according to the classification of fields at the same levels, and they have the same, if necessary only minimally different, name. Table 2 presents basic outputs of the level of regional normatives. 
Table 2

Comparison of regional normatives in 2006 and 2016 by categories of educational fields

\begin{tabular}{lllllll}
\hline Year & 2006 & & 2016 & & $2006-2016$ \\
\hline $\begin{array}{l}\text { Category } \\
\text { of fields }\end{array}$ & $\begin{array}{l}\text { Average } \\
\text { normativ } \\
\text { (CZK) }\end{array}$ & $\begin{array}{l}\text { Median } \\
\text { (CZK) }\end{array}$ & $\begin{array}{l}\text { Average } \\
\text { normativ } \\
\text { (CZK) }\end{array}$ & $\begin{array}{l}\text { Median } \\
\text { (CZK) }\end{array}$ & $\begin{array}{l}\text { Average increase } \\
\text { (CZK; \%) }\end{array}$ \\
\hline $\mathrm{H}$ & 28035 & 27897 & 48471 & 44071 & 20436 & 172.9 \\
\hline $\mathrm{K}$ & 23605 & 23605 & 32994 & 32994 & 9389 & 139.8 \\
\hline $\mathrm{L}$ & 27644 & 26811 & 42042 & 34707 & 14398 & 152.1 \\
\hline $\mathrm{M}$ & 26880 & 26254 & 36720 & 35119 & 9840 & 172.9 \\
\hline
\end{tabular}

From Table 2 we can calculate that in the area of graduation courses $(\mathrm{K}, \mathrm{L}, \mathrm{M})$ the average increase amounts to $147.9 \%$ in 2016 compared to 2006. Average support increases more markedly within apprentice courses H (172.9\%). Opposed trend is evident in the context of the above information. On the one hand, there is a considerable increase in financial support for apprentice schools, on the other hand they are reduced in terms of the number of places in schools (due to abolition and merging of schools). Their reduction is often at the expense of general oriented graduation courses such as grammar schools. It turns out that apprentice schools are problematic part of educational system in the Czech Republic.

Table 2 also shows that normatives in 2006 were much more balanced than in 2016, where we can observe significant differences even exceeding CZK 15,000. The increasing diversification of funding in various fields of study is therefore clearly evident. Apprentice schools receive on average the biggest financial support. It is both due to their need for labour market, but also a higher level of practical training, which is more expensive than theoretical teaching. Considerable differences exist, however, in support of various disciplines and the average is somewhat misleading figure because it is influenced by extreme values. These relate mainly to technical fields that are challenging for material conditions. Therefore, the table also shows the median value, which is in both years significantly lower (compared with the average) in all categories of fields except for category $\mathrm{K}$ (grammar schools). Although the average subsidy is the lowest in category $\mathrm{K}$, we must realize that the demands of practical teaching is not listed here, and if we compared only expenditure on theoretical teaching, the situation would be completely reversed and grammar schools would appear as strongly supported (as can be seen from Table 3, the cost of vocational training may even exceed the cost of theoretical teaching, as in the fields of category $\mathrm{H}$ ). 


\section{Acta Technologica Dubnicae \\ volume 7,2017 , issue 1}

If we look at the growth of support in the fields in last 10 years, we can see that it is most significant in the fields in category $\mathrm{H}$ and $\mathrm{M}$ (apprentice schools, vocational schools and lyceums), while the lowest increase is in fields in category $\mathrm{K}$ (grammar schools). But we must point out that we present the average indicators for the whole country and the situation is more complicated both in terms of specific fields of study (due to various specializations they have vastly different requirements for provision of teaching especially in practical training) but also in terms of regions (they labour markets have different needs). We recall that total normative in categories $\mathrm{L}$ and $\mathrm{H}$ is composed of two parts: the amount of theoretical and vocational training, as shown in Table 3.

Table 3

Comparison of regional normatives in 2006 and 2016 in the fields of vocational education

\begin{tabular}{llllll}
\hline Category & $\begin{array}{l}\text { Components of } \\
\text { normatives }\end{array}$ & $\begin{array}{l}\text { Average } \\
2006 \\
(C Z K)\end{array}$ & $\begin{array}{l}\text { Average } \\
2016 \\
(\text { CZK) }\end{array}$ & $\begin{array}{l}\text { Average increase } \\
\text { in years 2006 - 2016 } \\
\text { (CZK; \%) }\end{array}$ \\
\hline $\mathrm{L}$ & vocational training & 10240 & 15420 & 5181 & 150.6 \\
\cline { 2 - 7 } & theoretical teaching & 17404 & 23889 & 6485 & 137.3 \\
\hline $\mathrm{H}$ & vocational training & 14432 & 21536 & 7104 & 149.2 \\
\cline { 2 - 6 } & theoretical teaching & 13603 & 18385 & 4783 & 135.2 \\
\hline
\end{tabular}

Distribution of funds for vocational training and theoretical teaching corresponds to their ratio within the fields - fields of study in category $L$ have typically much more theoretical training, while apprentice courses $(\mathrm{H})$ have the ratio of theoretical and practical training more balanced (here, regardless of the financial demands in various fields).

Now we focus on a comparison according to specialization in selected areas. The selection of them is not random. We concentrate on the sectors that existed in 2006 under the same name and in the same category as in 2016. The analysis includes only courses for which complete data on regional normatives for both years are available. Thus, a broad spectrum of fields is reduced to just 18 , because all the other came through considerable changes (after 10 years they are newly designed and/or put into another category). Therefore, they cannot be regarded as comparable. It is necessary to realize that also these 18 fields now exist in different social situation and different rules for setting normatives. It, of course, limits the relevance of the comparison. Also, there was a shift in the concept and content of compared fields and that is why the results are rather tentative. 
Table 4

Average regional normatives by fields of study

\begin{tabular}{|c|c|c|c|c|c|c|}
\hline Year & 2006 & & 2016 & & \multicolumn{2}{|c|}{$2006-2016$} \\
\hline Field of study & $\begin{array}{l}\text { Average } \\
\text { normative } \\
(C Z K)\end{array}$ & $S D$ & $\begin{array}{l}\text { Average } \\
\text { normative } \\
(C Z K)\end{array}$ & $S D$ & $\begin{array}{l}\text { Averag } \\
\text { increas } \\
\text { (CZK; }\end{array}$ & \\
\hline Mechanic \& Electrician L & 29552 & 2104 & 35711 & 1906 & 6159 & 120.8 \\
\hline $\begin{array}{l}\text { Farm machinery } \\
\text { repairman } \mathrm{H}\end{array}$ & 28653 & 2578 & 37599 & 2772 & 8946 & 131.2 \\
\hline Medical assistant $\mathrm{M}$ & 31570 & 1680 & 41901 & 3156 & 10331 & 132.7 \\
\hline Hotel 1 & 26918 & 1830 & 36011 & 2262 & 9093 & 133.8 \\
\hline Cook - & 26480 & 1873 & 35805 & 2596 & 9325 & 135.2 \\
\hline Business a & 24543 & 799 & 33616 & 1163 & 9073 & 137.0 \\
\hline Electro & 26174 & 877 & 36317 & 3027 & 10144 & 138.8 \\
\hline $\begin{array}{l}\text { Grammar school (4 } \\
\text { years) K }\end{array}$ & 23605 & 745 & 32994 & 1114 & 9389 & 139.8 \\
\hline Construction industry M & 25881 & 872 & 37107 & 3168 & 11226 & 143.4 \\
\hline Agribussines M & 29098 & 2027 & 42135 & 5588 & 13037 & 144.8 \\
\hline rvices L & 26811 & 2255 & 39267 & 10946 & 12456 & 146.5 \\
\hline Bricklayer $\mathrm{H}$ & 27355 & 1893 & 45038 & 8817 & 17682 & 164.6 \\
\hline Joiner $\mathrm{H}$ & 31321 & 3368 & 52086 & 9347 & 20764 & 166.3 \\
\hline ales & 25965 & 2261 & 43341 & 7972 & 17377 & 166.9 \\
\hline Iairdr & 26136 & 1571 & 44071 & 1821 & 17935 & 168.6 \\
\hline Tetal & 28047 & 1701 & 56622 & 6633 & 28575 & 201.9 \\
\hline octricio & 31312 & 2365 & 67083 & 15163 & 35771 & 214.2 \\
\hline ifectionel & 20 & 2661 & & 35 & 32382 & 221.9 \\
\hline
\end{tabular}

Branches in Table 4 are sorted by the average increase (in \%) of financial support in the years 2006 - 2016. As the notional reference category, we can choose traditional grammar schools. They do not belong among the best-funded fields, but we dare to say that they are among the less costly disciplines (because of their strongly theoretical base), and they therefore can be considered as highly supported in both years.

As we can see, financial support is mostly increased in the fields from category $\mathrm{H}$, in three cases it is even more than doubled. There are interesting data on the standard deviation (SD), which expresses how greatly the support varies across 14 regions of the country. In 2006 and 2016 the smallest differences are among grammar schools and business schools (i.e. relatively widely conceived fields without practical training). If we search for the major differences in the support, 


\section{Acta Technologica Dubnicae \\ volume 7, 2017, issue 1}

we can find them in vocational courses (in 2006 it is Joiner, Confectioner and Farm machinery repairman, in 2016 it is Electrician, Cosmetic services and Confectioner). This is due to the situation on the labour market, which is different in 14 regions, but also due to different needs for material conditions of specific study courses.

\section{Discussion}

In the discussion, we will focus on the issues arising from the information presented. Educational policy seeks to reflect past and current situation of secondary education. In education, however, there are many factors that cannot be clearly monitored and evaluated. The analysis of White Paper (2009) testified it. It blames mainly the recent economic crisis, but also long-term instability of the Czech government, leading to inconsistent educational policy. Although there are efforts to gradually modify the system of funding schools so that it is more flexible, we are still unable to better reflect the current needs of the labour market (LPE 2015 - 2020, p. 21). It turns out that even supported courses often have high levels of unemployment, e.g. gastronomy, construction industry, food industry or wood processing have a long-term unemployment around $20 \%$, as apparent from LPE 2015-2020 (p. 24). On the contrary, the demand for graduates in other fields is met with no response, mainly in positions as craftsmen and labourers (often apprenticeships) but also salespeople, technicians and other specialists (NUV, 2015, p. 33). It appears, therefore, that we should give even more support to strengthen vocational and apprentice fields of study. They not only need financial support, but they also need to increase the motivation of primary school pupils who are not interested in them. In Czech society, there is still a prejudice that vocational fields (mainly apprentice schools) are not prestigious and that they lead to manually-intensive and poorly paid professions. It is also necessary to create more learning opportunities in these fields. They are reduced for the benefit of generally focused fields like grammar schools. These are currently accessible to a mass of almost anyone who wants to postpone the decision on their specialization to the level of tertiary education.

The situation should also be reflected in terms of European policy, which supports increasing percentage of highly educated population and lifelong learning in all EU countries. This helps grammar schools and all graduation fields of study, and at the same time leads to reduction in apprentice fields. This is evidenced by the decision to support not only technically and naturally oriented sectors, but also grammar schools (LPE 2015-20, p. 31), which represent the current trend of secondary school as a unifying mass preparation for universities and lifelong learning. Other authors write about education policy at secondary level and take notice of similar trends. For example, Erikson 


\section{Acta Technologica Dubnicae \\ volume 7,2017 , issue 1}

discusses integration of academic and vocational programmes leading to unification and quasi equality on the level of upper secondary schools in Sweden (2016). Abadzi (2016, p. 253) points out, that governments should "deemphasise basic knowledge and focus instead on complex cognition" in the context of apprentice education and on the base of cognitive science.

\section{Conclusions}

Educational policy in the Czech Republic is traditionally an issue that is relegated to the background. The funds, which are inserted into education, are below the long-term average of the EU and OECD countries. Additionally, we are still struggling with changes in our government and the endless transformation of the educational system. School workers also have to cope with changing concept of schools, which are seen as part of the educational market, where competition works.

The aim of the article was to point out some problematic aspects of the situation of secondary schools in the Czech Republic. On the one hand there is a reduction of vocational and apprentice schools, on the other hand we are increasing financial support to their fields of study. Under the 2004 law, each school has an individual curriculum known as the school educational program, but realistically, we see that the curriculum at secondary school level of education rather standardises. Unified state school leaving examination (maturita) also contributes to this trend. On the labour market, we need graduates of vocational and apprentice schools, but we still strongly support grammar schools and other theoretically oriented schools, whose graduates are not motivated for manual professions and often continue on universities.

It should be noted that the situation is not as simple as it may appear in this text. Educational policy is very complicated, because education is difficult to control and it is based on freedom of access. Therefore, the most important target for the future is to stabilize the situation and be able to reflect maximum of factors influencing secondary education in our society. At the end of this study we would like to express our concern over the declining share of apprentice schools in the Czech educational system. Although current trends clearly support lifelong learning and its unification, we should not forget the specific fields, which are often manually based (not based on general soft skills) that are needed on the labour market. Educational science should also give more attention to apprentice schools, because they are still overlooked and underestimated (there are not many examples of Czech research in this area, let us mention Kantorová, 2015). 


\section{Acta Technologica Dubnicae \\ volume 7,2017 , issue 1}

\section{References}

Abadzi, H. (2016). Training 21st-century workers: Facts, fiction and memory illusions. International Review of Education, 62(3), 253-278. Retrieved from: http://link.springer.com/article/10.1007/s11159-016-9565-6

Barták, F. et al. (2004). Odborné vzděláváni v České republice. Přehledová zpráva. Praha: ReferNet. Retrieved from: http://www.msmt.cz/vzdelavani/ skolstvi-v-cr/system-vzdelavani-v-cr

Česko. Nařízení vlády č. 211/2010 Sb., o soustavě oborů vzdělání v základním, středním a vyšším odborném vzdělávání. Zákony pro lidi.cz. (C) AION CS 2010-2016. Retrieved from: http://www.zakonyprolidi.cz/cs/2010211\#oddilB

Česko. Vyhláška č. 364/2005 Sb., o vedení dokumentace škol a školských zařízení a školní matriky a o předávání údajů z dokumentace škol a školských zařízení a ze školní matriky (vyhláška o dokumentaci škol a školských zařízení). Zákony pro lidi.cz. (C) AION CS 2010-2016. Retrieved from: http://www.zakonyprolidi.cz/cs/2005-364

Česko. Vyhláška č. 492/2005 Sb., o krajských normativech. Zákony pro lidi.cz. (C) AION CS 2010-2017. Retrieved from: https://www.zakonyprolidi.cz/ cs/2005-492

Dlouhodobý zámér vzdělávání a rozvoje vzdělávací soustavy České republiky na obdobi 2015-2020. Retrieved from: http://www.msmt.cz/vzdelavani/ skolstvi-v-cr/dlouhodoby-zamer-vzdelavani-a-rozvoje-vzdelavaci-soustavy$3^{8}$

EACEA. (2009). Organizace vzdělávací soustavy České republiky 2008/09. Retrieved from: http://www.msmt.cz/vzdelavani/skolstvi-v-cr/systemvzdelavani-v-cr

Erikson, J. (2016). A School for all or a School for the Labour Market? Analyzing the Goal Formulation of the 1991 Swedish Upper Secondary Education reform. Scandinavian Journal of Educational Research. Retrieved from: http://www.tandfonline.com/doi/abs/10.1080/ 00313831.2015 .1119726

Eurostat. (2016). International Standard Classification of Education (ISCED). Retrieved from: http://ec.europa.eu/eurostat/statistics-explained/index.php/ International_Standard_Classification_of_Education_(ISCED)

Hužovičová, M., \& Jakúbek, P. (2014). The Lifelong Learning in the Field of Employment Policy in Slovakia. Acta Technologica Dubnicae, 4(2), 27-35. doi: 10.1515/atd-2015-0003

Janík, T., Spilková, V., \& Píšová, M. (2014). Standard a kariérní systém učitele: problémy předložené koncepce $\mathrm{v}$ širších souvislostech. Pedagogická orientace, 24(2), 259-274. doi: http://dx.doi.org/10.5817/PedOr2014-2-259

\footnotetext{
${ }^{8}$ In the text, cited under the abbreviation "LPE"
} 


\section{Acta Technologica Dubnicae \\ volume 7,2017 , issue 1}

JuSeuk, K. (2016). Development of a global lifelong learning index for future education. Asia Pacific Education Review, 17(3), 439-463. Retrieved from: http://link.springer.com/article/10.1007/s12564-016-9445-6

Kantorová, J. (2015). Školní klima na školách poskytujicích střední vzdělání s výučním listem. Olomouc: Univerzita Palackého v Olomouci.

MEYS. (2009). O prijímacím řizení - leden 2009. Retrieved from: http://www.msmt.cz/vzdelavani/stredni-vzdelavani/o-prijimacim-rizenileden-2009

MEYS. (2014). Strategy for Education Policy of the Czech Republic until 2020. Retrieved from: http://www.vzdelavani2020.cz/images_obsah/dokumenty/ strategy_web_en.pdf

MEYS. (2016). Vláda schválila kariérní ř́d pro učitele. Retrieved from: http://www.msmt.cz/ministerstvo/novinar/msmt-pripravilo-karierni-radpro-ucitele?lang=1

MEYS. (2017a). Porovnáni krajských normativi mzdových prostředků a ostatnich neinvestičnich výdajů stanovených jednotlivými krajskými úřady pro krajské a obecni školstvi v roce 2016. Retrieved from: http://www.msmt.cz/vzdelavani/skolstvi-v-cr/ekonomika-skolstvi/ porovnani-krajskych-normativu-mzdovych-prostredku-a-4

MEYS. (2017b). Porovnáni krajských normativi mzdových prostředki stanovených jednotlivými krajskými úruady v roce 2008. Retrieved from: http://www.msmt.cz/vzdelavani/skolstvi-v-cr/ekonomikaskolstvi/porovnani-krajskych-normativu-mzdovych-prostredku

MEYS. (2017c). Statistické ročenky školství. Retrieved from: http://www.msmt.cz/vzdelavani/skolstvi-v-cr/statistika-skolstvi/rocenky

MEYS. (2017d). Výkonová data o školách a školských zařizeních - 2003/04 2013/14. Střední školy. Retrieved from: http://www.msmt.cz/vzdelavani/ skolstvi-v-cr/statistika-skolstvi/vykonova-data-o-skolach-a-skolskychzarizenich-2003-04-2013

Národní program rozvoje vzdělávání v České republice: Bílá kniha. (2001). Praha: Tauris. ${ }^{9}$

NUV. (2015). Uplatnění absolventů škol na trhu práce - 2014. Retrieved from: http://www.nuv.cz/uploads/Vzdelavani_a_TP/Uplatneni_absolventu_za_ro k_2014_pro_www.pdf

NUV. (2016). Stupně středního vzdělání. Retrieved from: http://www.nuv.cz/ t/stredni-vzdelavani

Zpráva o vývoji českého školství od listopadu 1989. Retrieved from: www.msmt.cz/file/10376_1_1/download/ ${ }^{10}$

\footnotetext{
9 In the text, cited as "White Paper"

${ }^{10}$ In the text, cited as "Development Report"
} 